\title{
The landmark of Cronulla
}

Jock Collins

In Sydney on Sunday, 11 December 2005, riots on Sydney's Cronulla beach sent a tremor through Australian community relations. Images of thousands of mainly drunk white males chasing and bashing isolated men and women of 'Middle Eastern appearance' were compelling viewing for media audiences in Australia, and overseas (Poynting 2006). Days later, a retaliatory gang of males of 'Middle Eastern appearance' sought revenge in a smash, bash and flee raid in their cars on the suburbs surrounding Cronulla. For months afterwards, an unprecedentedly large police presence dominated the sandscape of Sydney's famous beaches, successfully preventing further reverberations and escalation of racial conflict. The ramifications and significance of these events should not be underestimated.

Sydney is one of the greatest immigrant cities in the world today. At the 2001 Census 58 per cent of Sydneysiders were first- or second-generation immigrants, with some 180 birthplaces recorded for the city's resident population. Australia overall has, in relative terms, more immigrants from a greater diversity of backgrounds than most countries in the world today, making it one of the most cosmopolitan of contemporary Western nations.

To some international commentators (Huntington 1997, 2004), the clash of ethnicities and religions, mostly a product of immigration policies, threaten Western societies in fundamental ways, particularly after 9/11. Recent events overseas and in Australia associate immigration and ethnic diversity with conflict and violence. To the critics of Australian immigration and multiculturalism, these riots, combined with instances of ethnic conflict in Europe and North America, were confirmation that immigrant minorities inevitably bring conflict to their host country, threatening social cohesion and dividing the nation, particularly when these immigrants include minorities from Asia, the Middle East and Africa. 
But can these conclusions be derived from the Cronulla incident? In order to help gauge the severity of the social conflict at Cronulla beach, and get a sense of proportion, it is important to review other incidences of ethnic conflict and violence involving immigrant minorities internationally and in Australia. and violence involving immigrant ming in Australia and This chapter explores inter-ethnic and intra-ethic violence in Australia and other countries to provide a lens for viewing the Cronulla riots. It also investigates the context of the riots and explores how they help to understand the relationship between immigration, ethnic diversity and social cohesion and conflict in Australia. The chapter also considers the policy implications of the riots, flict in Australia. The chapter alo con including the lessons for Australian multicultural policy and other responses in Sydney.

The events at Cronulla beach can only be understood within the broader lens of the changing, and uneven, processes of the racialisation (Miles 1989, 1993) of of the changing, and in Australia and what determines it. The chapter concludes imming that cohesion and conflict coexist in cosmopolitan Australian sociey, with most evidence suggesting that cohesion is the norm and conflicts such as Cronulla the exception. Nevertheless, Cronulla provided a wake-up call against complacency; it reminded us of the challenges and benefits in cosmopolitan societies and the political responsibilities of leaders to manage ethnic diversity, as well as the dangers of political opportunism in exploiting racist undercurrents for shortterm electoral ambition.

\section{Theoretical aspects}

Social cohesion is hard to define and study. Its opposite is social conflict. But all societies exhibit conflict between different groups over time, oscillating between moments of cohesion and conflict. How much or what kind of conflict shifts a moments from cohesive to divisive? In making this judgement, it is also importan society from cominist to acknowledge that social conflet in not ne movementin Western countries like Australia in the latter part of the 20 th century, for example, had to confront existing power structures and ideology to gain a footing for gender equality. And the African National Congress, led by Nelson footing for gender equall treme forms of conflict to overturn apartheid in South Mandela, had to resort to extremetaphor of good and bad cholesterol is useful here: what sorts of conflict - when, where and between whom - are good and what what sorts of conflict - when, where and between whom - are good and what partly on different interpretations of particular instances of social conflict.

According to the Marxist view of capitalist society, class conflict is the driving force of history; a society without it would be one without a past, present and future. On the other hand, Talcott Parsons (1949: 182-99) saw cohesion as a central category, with society held together by shared values in which every individual or subsystem had a function conducive to the well-being of the whole. Conflict in this sense was 'dysfunctional'.

For the Chicago school of sociology, conflict by ethnic groups was a necessary stage in the path to successful immigrant assimilation. In Robert Park's (1922) early theory of a 'race relations cycle', ethnic conflict was an inevitable but intermediate stage that all new ethnic groups traversed on the way to assimilation
in a Western metropolis:

The most obvious source and origin of most, if not all of the cultural and racial conflicts the 'other groups'... They are in fact, are, therefore, conflicts of the 'we groups' and the 'other groups' ... They are, in fact, individual instances of an irrepressible conflict between the folk culture of the provinces and the civilization of the metropolis. (Park
2000)

Other approaches to ethnic conflict see conflict or prejudice as emerging from human nature, relegating racism to human pathology (Ardrey 1967). Social psychological approaches, on the other hand, relate individual attitudes which lead to conflicts - such as racism and prejudice - to social problems and social structures. Hence Max Weber (1970) saw ethnic conflict as a rational behaviour of ethnic groups designed to maximise the IR power in the Cope and colleagues (1991: 26) argue, this ignores class relations and the links between economic and political power.

\section{International views}

Inter-ethnic conflict in Western societies has appeared regularly on television screens in the past few decades. In the most extreme recent examples - the 'ethnic cleansing' in Bosnia and the mass slaughter in Rwanda - the conflict was not related to diverse immigration programs, and Yugoslavia was a country of emigration rather than immigration. Most other European and North country of emitries with varying histories of international migration have seen involving settler minorities (Castles \& Miller 2003).

Britain experienced 'race riots' in Brixton in the early 1980s (Solomos 1989). Decades later in 2001, ethnic conflict ignited in Burnley and Oldham (Ascherson 2002). While the causes of these conflicts are complex, the Stephen affair identified racist policing as one key underlying element. The 1999 Macpherson report (Cathcart 2000) into the death of Stephen Lawrence exposed the extent of police racism in Britain and proposed a series of police reforms. Young men of Afro-Caribbean and Asian background were the focus of this conflict. Following the bombing of the London Underground on 7 June 2005, youth of Middle Eastern and/or Muslim background have been 7 tune 2005, youth of to British society.

In the Netherlands, Pym Fortuyn's rapid rise into the Dutch political limelight in 2002 ended with his assassination on 6 May, just nine days before he could test national support for his List Fortuyn party in national elections. Fortuyn was opposed to Muslim immigrants and had argued that 90 ections. Fortuyn crime in Rotterdam was committed by Mrod argued that 90 per cent of street 2002), once again linking recent ethnic conflict to aller immigrants (Osborn More recently, the Dutch filmt ethnic conflict to alleged ethnic criminality. made an anti-Islamic film Inmaker Theo Van Gough was murdered after he that was seen as threatening this instance it was the Muslim immigrant minority 
In France in November 2005, following the electrocution of two Muslim youth In France in Nover fleeing from police, their kinsfolk who lived in the pub that spread to many other north-western suburbs of Paris initiated a series of riots that spread to many on with suburbs for nearly a month. Thousands of cars were burnt and confrontation with pulice and authorities a nightly occurrence. The unemployment rate for Muslim police and authorith a nigh uburbs, characterised by poor public housing, was youth in these north-western 2005 ).

over 50 per cent (Symons 2005).

None of these instances of social conflict involving immigrant minores 'race Europe could match the extent of the conflict generated in the Los Angeles race riof' 1992. When the flames were doused and law and order restored to the riots' of May 1992. When the flas magnitude of the social conflict emerged: 54 dead; streets of LA, the enormous magnitude of the social conflict 5200 buildings damaged or destroyed by 2383 injured; 17000 people arrested; 5200 buildings dam 1992, p. 45). This was fire; losses estimated to be \$US1 billion (Newsweek 18 May 1992, p. 45). This was not a simple black versus white conflict. Black Americans joined recent Latino not a simple black vtreets in looting and rioting. Their anger, born out of persistent immigrants on the streets an political disenfranchisement, was not just directed at economic disadvantage and political disenfranchimigrant entrepreneurs who owned white LA police but also at wealthy Korean inm elsewhere. This was not a race but businesses in black a

a cosmopolitan riot. In the same month in 1992 in Toronto, Canada's largest immigrant city, mob of about 1000 ponday Night vandalising property and breaking into stores Toronto streets on Monday sight 'Toronto riot' shocked Canadians more than the (Globe and Mail 6 May 1992). The 'Toronto riot' shocked Canadians inself in being a events in LA: Canada in general and Toronto in particular prided itseff in being tolerant, multicultural society where all cultures mingle freely and equally. Like tolerant, multicultural society where all cund to be a major factor in the Toronto the LA riots, racism (Collins \& Henry 1994).

killing (Collins \& Henty 1994).

These instances of ethnic or racial conflict in Europe and North Amities at the a number of things in common. The young male immigrant minom socially disadvantaged families centre of the conflict, had problems identifying with the mainstream of the new and neighbourhere society. In each case, relations between immigrant minorith subsequent inquiries and during the events of ethnic conflict were a catalyst, with subsequent often recommending substantial changes to the methods, attitudes and practices of police. In each case right-wing p

and anti-multiculturalism rhetoric

\section{Australian perspectives}

In the history of Australian immigration before 1947, conflict and violence In the history of Australian immigration befor the 19th century anti-Chinese appeared at regular intervals. In the middle of the 19th century anting Bendigo riots occurred on many goldfields, including at Hanging Rock in 1852, Bendigo in 1854, Buckland River in 1857 and Lambing Flat in 1861 (McQueen 1970:44-5) Massive mobilisation against Chinese immigrants in New South Wales and VicMassive mobilisation against Che Queensland canefields laid the ground for the toria and Kanaka labour in the Queensland canefiation in 1901, with unusually widespread support (Price 1974; Saunders 1975: 180; Markus 1979). In the first decades of the 20th century, the opposition to Southern European immigrants from Greece and Italy, who replaced Chinese immigrants as unskilled labour led to violence and conflict that derived from in the that reported in 1925, 'Australia's fear and suspicion of Southern Europeans' (de Lepervanche 1975: 98-9). In 1934 anti-Italian riots occurred in Melbourne when Italian immigrants were used as strike-breakers by employers on Melbourne's wharves. An even more serious conflict occurred the same year in Kalgoorlie when more than a dozen shops owned by Southern European immigrants were looted and at least five Italian, Greek and Slav clubs and hotels were burnt to the ground (Price 1963: 210). At least two people died and countless others were wounded, with Church (2005: 188) describing these events as 'Australia's worst race riot?.

After World War II, following the start of the ambitious postwar immigration program, instances of inter-ethnic conflict are hard to find. It is true that there are records of a number of antisemitic activities; of conflict between Vietnamese and Turkish youth in Broadmeadows, Melbourne (Chauvel \& Petanszki 1986); and of Greek community marches in the late 1980s opposing the naming of Macedonia. There were also clashes between supporters of ethnically based soccer teams, such as that of 2004-05 in Sydney at matches between teams with Serbian and Croatian followers. This led Soccer Australia to end ethnically based teams and develop a national competition of city-based ones (the National Soccer League) In February 2007, fights between supporters of two Sicilian teams led to the death of two policemen and the suspension of the Italian Series A and all other football competition. But when judged against earlier Australian experience, or recent international experience of ethnic conflict, it is difficult to avoid the conclusion that the post-1945 Australian immigration experience has been remarkably free of serious ethnic conflict.

Among the worst instances of inter-ethnic conflict in Australia in the postwar period are those suffered by Muslim, Sikh and other visible minorities following the Desert Storm war in 1990 and the invasion of Iraq in the early 2000s. One consequence of these events, for example in the early 1990 s, was that Australians of a Muslim and/or Arab background were subject to extensive racial vilifica. tion, abuse and physical attacks (HREOC 1991). A report by the Committee on Discrimination Against Arab Australians (1992) documented racist incidents against Arabs and Muslims for the period November 1990 to July 1991. Many families reported harassment at their homes and in the streets, shopping centres, schools and communities. Many women wearing the hijab thopping centres, from passing cars and in parking lots. Physical violence was also widespread, with reports of Arabs being spat at or incurring physical injury, including women
who had their hijab pulled or torn. In one incident, a car was deliberately run into and damaged, while in another an Arab man died of a heart attack after being racially harassed by a group of teenagers. Widespread property damage was also reported. A Muslim school and restaurant in Perth, Western Australia, were subject to arson attacks after threatening phone calls, and in other homes and restaurants broken windows and graffiti were common. Many mosques and offices of Arab and Muslim organisations were attacked repeatedly, while staff 
received threatening phone calls and mail threats. One Islamic Centre in one received the suburb was fire-bombed in January 1991

uter Sydney suburb was fire-bonbed in New South Immediately after the events of 9/11, a Hot Line established in $\mathrm{New}$ South Wales on 13 September 2001 recorded a significant number of incidents of physical, verbal and sexual assault; threat; racial discrimination or harassment, and ical, verte this was mostly directed at Australians visibly of a damage to property. While this was most victims were female with over half of all Muslim or Arab background - half of all victims were female with over haups, with calls received from Arabic speakers - it was not confined to these groups,

Australian Sikhs also reporting abuse and violence (UTS Shopfront 2005).

A national consultation by the Human Rights and Equal Opportunity Commission (HREOC), with 1423 Arab and Muslim Australians, conducted an audit of 100 local and state government groups and community organisations after $9 / 11$ and the first Bali bombing. It found that most Muslims consulted had race or enced escalating prejudice that ranged from 'offensive remarks about race or religion to physical violence' (HREOC 2004: 2). The report noted that 'peoreligion to physical violence (Huslim because of their dress or appearance were ple readily identifiable as Muslim be and abuse' and that 'Muslim women who particular targets of racist violence and abuse' and that 'Mus' (ibid.: 45). Physwear the hijab, niqab or chador have been especially ats risk (bid.. ical attacks, threats of violence and attempted assaults were widely reported ical attacks, threats of incidents of vandalism on what was identifiably the as were a number of incidentions or individuals, with one mosque in Queensproperty of Muslim organisations or indivind (ibid.: 49). These incidents were land fire-bombed and burnt to the ground (ibid.: 49 . These ind public transreported as having occurred on the street, at home, in private and pubic the and at
port, in shops and shopping malls, at school, college and university and at work.

\section{The Cronulla riots}

On 11 December 2005 Australian and international television screens carried shocking visual footage of a violent, drunken mob of some 5000 mainly 'white' mo male Australians, most with beer can in hand the few individuals of 'Middle flag, verbally abusing, attacking and beating the few individuals of 'Middle Eastern appearance' they could find nearby. The gathering was a widely publicised and promoted response to 'save our beaches' in the aftermath of a fight licised and promoted response to sa group of four Lebanese-background young between three surf lifesavers and a group of four weekend before. This fight was men that had occurred at Cronulla beach the weekend before. This fight wa widely reported and condemned as 'un-Australlan' in the Sydney print and elecwidely tronic media, which also reporto following weekend to by the Sydney tabloid the Telegraph - was to be held the followide support at the 'reclaim' the beach. Mobile phone text messages called on wide support at the

rally. The Telegraph ensured that those who were not party

This Sunday every Aussie in the Shire get down to North Cronulla to help support Le and wog bashing day ... Bring your mates and let's show them that this is our beach and they are never welcome ... let's kill these boys.
The shock-jocks used their airwaves to promote the rally. After reading out this message during his radio program on radio station $2 \mathrm{~GB}$, Alan Jones, one of the most prominent and widely syndicated of the Sydney shock-jocks, encouraged widespread support for the rallywith the words 'Come to Cronulla this weekend take revenge' (Poynting 2006). Callers to his program recounted many instances when young 'Aussie' women had been insulted by Muslim, Lebanese or Middle Eastern men who were alleged to have no respect for women (Manning 2006: 257-64). The call was clear: in the tradition of the ANZAC soldiers who died at Gallipoli, it was the duty of young red-blooded men to defend their women and their nation from the enemy within - immigrants from countries in the Middle East - on the sands of Cronulla beach.

Journalist Paul Sheehan (2006: 351-71) had a different perspective, telling the story of the young whites who sided with the mobilisation against the Lebanese/Muslim/Middle Eastern community. In this account the behaviour of Lebanese/Muslim/Middle Eastern males justified the response as a protest against racism (the racism of those of Middle Eastern appearance towards whites) and dismissed the arguments that those whites participating in the riots were in any way racist themselves (ibid.: 362 ).

What are the implications of the Cronulla riots for assessing social cohesion and racism? Some (ibid.) see the events as proof that Australia's immigration and multiculturalism policies are not working. This is ironic, since the program of Australian multiculturalism (Castles et al. 1988; Collins 1991) was dismantled after the election of the Howard government in 1996. Indeed, by the end of 2006 both the Howard government and the Labor opposition had replaced multiculturalism with 'integration' as the key word expressing the essence of Australia's settlement philosophy and policy for new immigrant settlers.

In my view, more multiculturalism, not less, is required. The roots of much disquiet among Middle Eastern minority youth in Australia and their conflict with white Anglo-Celtic youth lie more in the realm of socio-economic disadvantage, masculinity and youth subcultures than it does in ethnic difference. Issues of masculinity and territoriality have led to violence between groups of young men in Australia well before the postwar immigration program changed the face of Sydney and Australian society. Strategies related to education, employment, local neighbourhood facilities and infrastructures, policing and the media for immigrant minority youth are more likely to yield positive results than continual questioning of the functionality of the Australian immigrant communities. For decades Australian multiculturalism has emphasised policies and programs to help new immigrants at school, in the community and at work, as well as the right for the cultural and linguistic difference of immigrant minorities to be respected and expressed in public. The backbone of Australian multiculturalism policy, at least in its first decades, was social justice for all, irrespective of language or cultural or religious background. Today there is a need for an urgent revitalisation of Australian multiculturalism, not its abandonment.

The issue of Australian racism has also come into the spotlight since 9/11 (AntiDiscrimination Board of New South Wales 2003) and, more recently, Cronulla. To his credit, NSW Labor Premier Morris Iemma criticised the racism from the white crowds, and labelled their behaviour un-Australian. But racism is not 
exclusive to whites in Australian society. It has emerged from elements of exclusive to whites in Australian society. It has energed from involved in the Lebanese and Middle Eastern communities - including those from many other retaliation violence after the Cronulla beach riot - as well as from many o cenimmigrant and indigenous minorities. It suggests that anti-racism must be a cenimmigrant tral plank of Australian multeulured to

and renew it are required today.

Other commentators have seen in the events of Cronulla a fulfilment of Geoffrey Blainey's fears (1984) that non-British immigrants were a threat to cohesion. However, the fact that the events of Cronulla are so rare is evidence for a counterview, which is that, despite all odds to the contrary, Australia's ethnic diversity has occurred mainly without social conflict. People from all corners of the globe live in Sydney. At any moment some of Sydney's immigrant communities are in conflict somewhere in the world. And yet rarely does this international conflict conflict som into the streets and neighbourhoods of Australian life. It was popular overflow into the streets and nits 1992 that ethnic diversity will inevitably bring to conclude from the LA riots in 1992 that ethnic diverist. It is that unless everything is conflict. But the lesson of the LA riots is different. It is that unless every live and done to ensure that new immigrants have as much opportunity to work, live and participate in society at all levels as non-immigrants - and this was not the case in participate in soces where there is political disenfranchisement, social alienation, the United States, where ther - ethnic diversity will probably lead to conflict. and no adequate safety-nets - ethnic diversity tradition of multicultural proThe United States does not have the Australian tradition of multicul the ladde grams and services to assist new immigrants to settle and to climb up the ladder of American society. In this important sense Australian multiculturalism is the

safety-net that has helped steer our culturally diverse society
sion and away from social conflict between ethnic groups.

\section{Cronulla and multiculturalism}

The Cronulla riots were an expression of ethnic tensions in one of the world's The Cronulla rits wat cities. But set against the history of ethnic relations and ethmost cosmopolitan cities. But set againt the America, they hardly constitute sufnic conflict in Australia, Europe and North America, they hardly constite minorificient evidence to support the arguments of the critics of immigrant minorities and non-discriminatory immigration policy. The Cronulla beach riot did not ties and non appear in the frontline subu (Collins those south-western Sydney suburbs of Lakemba or Fairf there was personal injury et al. 2000), but in a white enclave. No one died, though there was personalinjury and property damage, as well as much undermining of Sydney's international and propert the riots were not the darkest of Australia's recent experiences with reputation. The riots were norn by Australia's Islamic or 'Middle Eastern appearethnic conflict, a badge wort $-9 / 11$ years.

ance' community in the post-9/1 included the international events of post-9/11, The background to Cronulla included the international events of post-9/11, the 2001 Australian national election and its contentious children overboard incident (Marr \& Wilkinson 2003), as well as the Sydney context of a politicalopportunist law-and-order debate built on the moral panic about ethnic crime (Collins et al. 2000; Poynting et al. 2004). Cronulla can thus also be in Australia. latest chapter in anti-Arabic and anti-Muslim inter-ethnic conflict in Australia.
In the words of journalist Peter Manning (2006: 266), 'we are in grave danger of seeing all Arabic and Muslim Australians as "the enemy". But the cloud of a crisis in social relations between Arab and Muslim Australians on the one hand and white Australia on the other has a silver lining: the realisation that these conflicts in Australia have not reached the levels of other countries today or earlier periods of Australian history. Prejudice and tolerance coexist in Australian history. That tolerance seems to win out on most occasions, however does not redress the ugliness or seriousness of the moments of inter-ethnic conflict anywhere in Australian cities.

The seriousness of Cronulla and the sentiments that propelled it should not be denied. In many ways, Cronulla is a wake-up call to Australian society, particularly its cosmopolitan metropolises. It exposed the ever-present tension between tolerance and prejudice, racism and multiculturalism, cohesion and conflict, and is a call to highly multicultural nations of the need to tread carefully: to nurture inter-ethnic relations and not undermine them for opportunistic political purposes. The Cronulla riots are a rather crude reminder of the responsibilities that go with non-discriminatory immigration policy at a time when increasing globalisation is increasing the size and diversity of immigration flows around the world.

The Los Angeles and Paris riots and others are sometimes cited as evidence that ethnic diversity means social conflict. Australian cultural diversity is now a permanent feature of contemporary and future Australian society, requiring a settlement policy designed to deal with diversity and to achieve social cohesion. An abandonment of multiculturalism is exactly the opposite of what is needed. The lesson from the LA riots is not that ethnic conflict is the inevitable consequence of a society becoming increasingly culturally diverse through immigration. Rather it is that culturally diverse societies require policies and programs, with substantial public sector investment; to give all people the opportunity of economic advancement, social inclusion and participation in public life and public spaces. The safety-net of social security payments and access to health, education and other services are important here. If ethnic diversity is not supported by welfare and other programs and services, particularly during the initial settlement period, the ensuing economic, social and political exclusion of ethnic minorities will threaten social cohesion. Consequently multiculturalism needs properly resourced programs of English language tuition, recognition of qualifications, translation services, education, health, housing and welfare programs, and services to help new immigrant minorities who are today keenly sought by Australia in a fierce global competition to fill labour market shortages and skill gaps. It also needs to resolve past weaknesses in multicultural policy, especially the place of Indigenous peoples. Multicultural policy can be developed to overcome these weaknesses, but it is not clear that a new integration policy would be able to do so. Unless integration policy aims to give all Australians every chance to participate equally and cohesively in all aspects of social and economic life, it is unlikely to succeed. 
AUSTRALIA HAS SUCCEEDED in harmoniously absorbing millions of immigrants from a great diversity of cultures. Divisiveness has been minimal. Indeed, Australia is one of the world's most cohesive societies: since 1788 it has never experienced revolution, invasion or assassination of a major public figure. Helping secure this outcome have been steady economic growth, high living standards, stable democratic institutions, and isolation from conflict. However, there is no denying that probjems have been encountered.

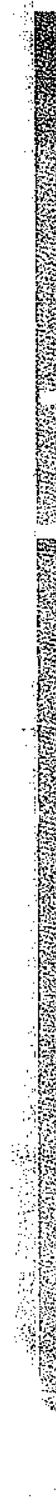

With contrioutions trom some of Australias s leading experts, this book addresses

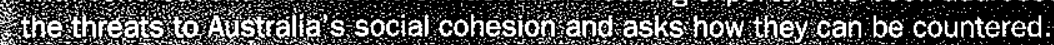

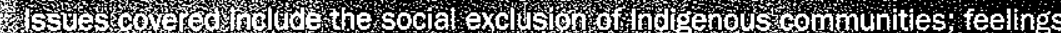
1.1.

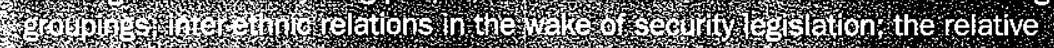

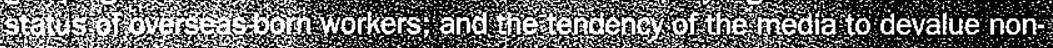

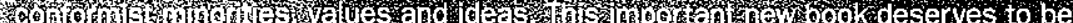

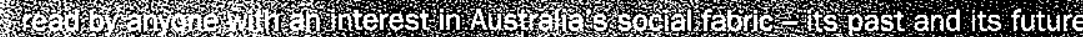

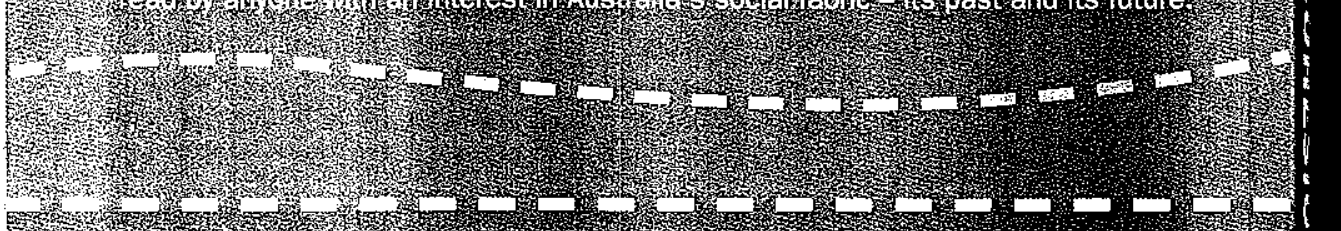

HAMES UP AM S V. 7.

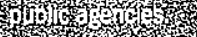

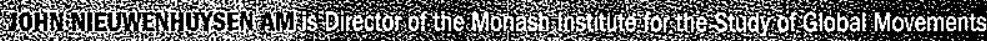
13.

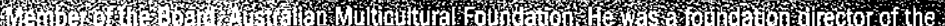
6.6.

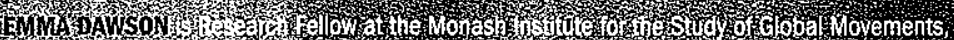

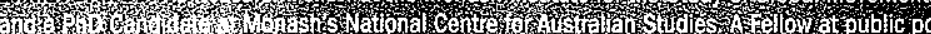

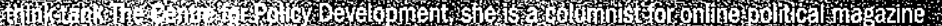

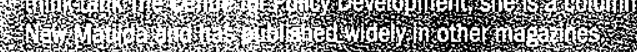

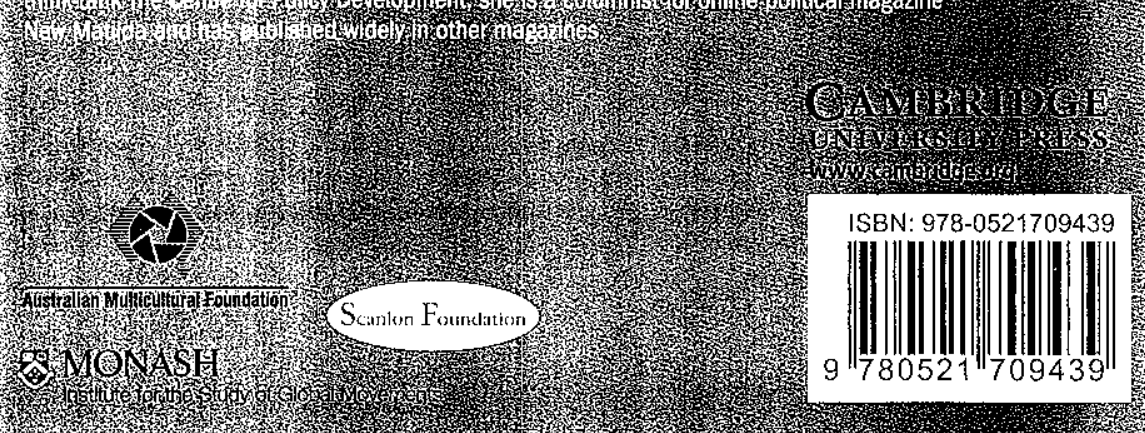
NAUSTRALIA

mes Jupp \& John Nieuwenhuysen Emma Dawson

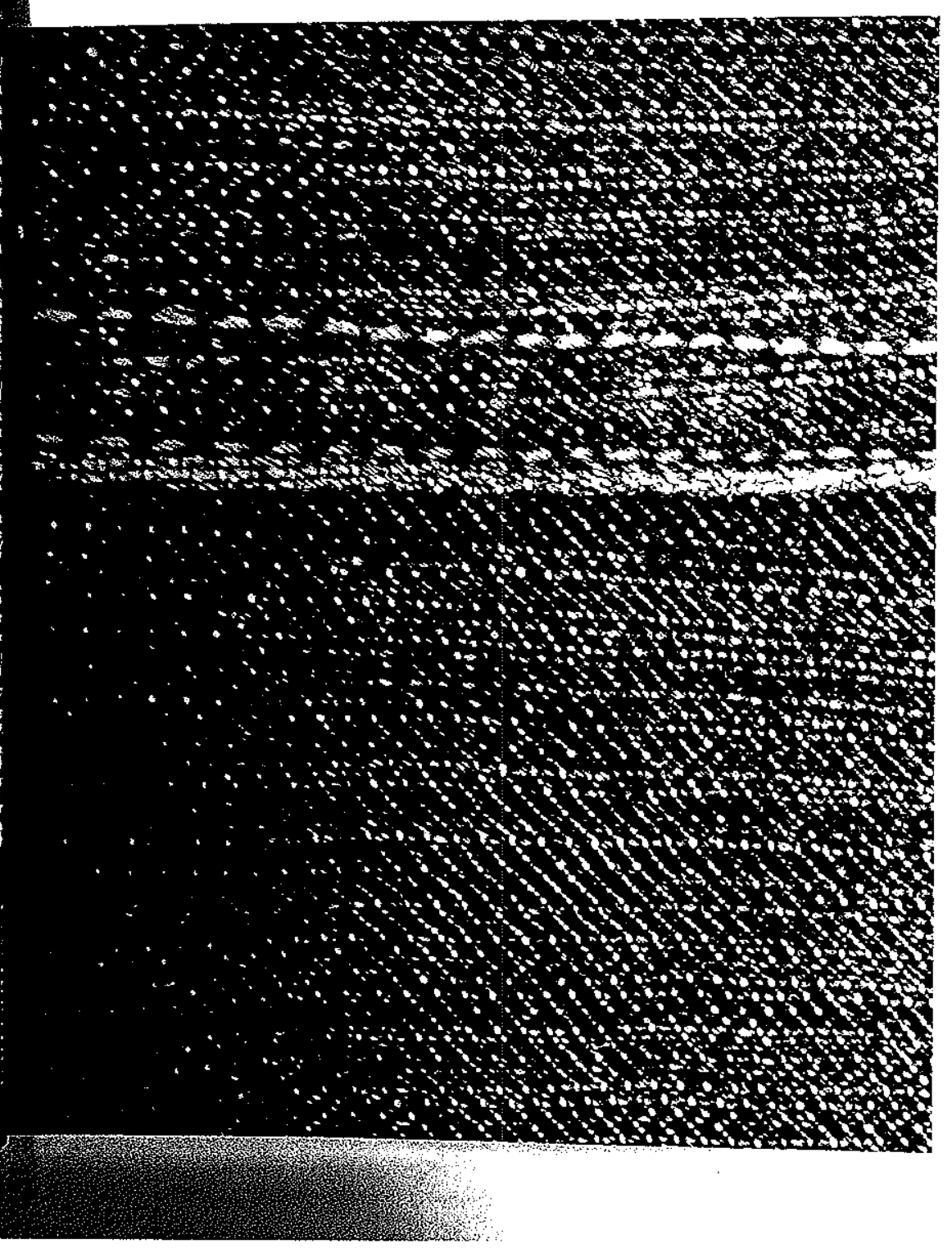




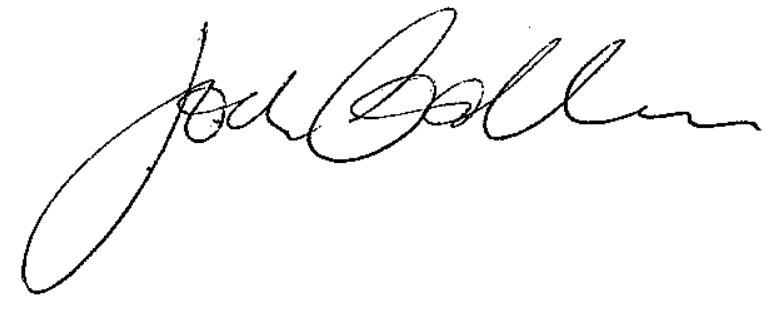

\section{Social Cohesion in Australia}

Australia has succeeded in harmoniously absorbing millions of immigrants from a great diversity of cultures. Divisiveness has been minimal. Indeed, Australia is one of the world's most cohesive societies: since 1788 it has never experienced one of the world's most cohesive societies: since 1788 it has never experienced
revolution, invasion or assassination of a major public figure. Helping secure this outcome have been steady economic growth, high living standards, stable democratic institutions, and isolation from conflict. However, there is no denying that problems have been encountered.

With contributions from some of Australia's leading experts, this book addresses the threats to Australia's social cohesion and asks how they can be countered. Issues covered include the social exclusion of Indigenous communities; feelings of marginalisation of young people; tension between mainstream and new religious groupings; inter-ethnic relations in the wake of security legislation; the relative status of overseas-born workers; and the tendency of the media to devalue nonconformist minorities, values and ideas. This important new book deserves to be read by anyone with an interest in Australia's social fabric - its past and its future.

James Jupp AM is Director of the Centre for Immigration and Multicultural Studies at the Australian National University (ANU). He has published widely on immigration and multicultural affairs and has acted as a consultant for the Office of Multicultural Affairs, the Department of Immigration and other public agencies.

John Nieuwenhuysen AM is Director of the Monash Institute for the Study of Global Movements. He is also a member of council, RMIT University; Chair of the Board, VITS Language Link, and a Member of the Board, Australian Multicultural Foundation. He was a foundation director of the Commonwealth Bureau of Immigration, Multicultural and Population Research.

Emma Dawson is Research Fellow at the Monash Institute for the Study of Global Movements, and a PhD Candidate at Monash's National Centre for Australian Studies. A Fellow at public policy think-tank The Centre for Policy Development, she is a columnist for online political magazine New Matilda and hâs published widely in other magazines. 


\section{Social Cohesion in Australia}

James Jupp \& John Nieuwenhuysen with Emma Dawson

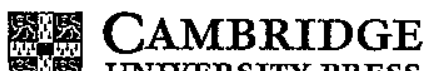

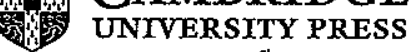


CAMBRIDGE UNIVERSITY PRESS

Cambridge, New York, Melbourne, Madrid, Cape Town, Singapore, São Paulo

Cambridge University Press

477 Williamstown Road, Port Melbourne, vIC 3207, Australia

Published in the United States of America by Cambridge University Press, New York

www.cambridge.org

Information on this title: www.cambridge.org/9780521709439

(C) James Jupp, John Nieuwenhuysen, Emma Dawson 2007

This publication is copyright. Subject to statutory exception

and to the provisions of relevant collective licensing agreements,

no reproduction of any part may take place without

he written permission of

\section{First published 2007}

Cover design by Design by Committee

Typeset by Aptara Corp.

Printed in Australia by Ligare

A catalogue record for this publication is available from the British Library

National library of Australia Cataloguing in Publication date

Jupp, James, 1932-

Social cohesion in Australis.

Includes index.

ISBN 9780521709439 paperback

1. Pluralism (Social cciences) - Australia. 2. Immigrants - Australia - Government policy 3. Race relations - Australia 4. Australia - Emigration and immigration - Government policy. I. Nienuson, Emma. III. Title po5.800994

TSBN 978-0-521-70943-9

\section{Contents}

Foreword vii

List of contributors viii

List of tables $\mathrm{x}$

Acknowledgments $\mathrm{x}$

Introduction 1

IOHN NIEUWENHUYSEN

PART I DEFINING, MEASURING AND SEEKING SOCIAL COHESION

1 The quest for harmony 9

JAMES JUPP

2 Conceptualising social cohesion 21

ANDREW MARKUS AND LIUDMILA KIRPITCHENKO

3 Measuring social cohesion in a diverse society 33 NICK ECONOMOU

4 Australian government initiatives for social cohesion 45 THE HON. KEVIN ANDREWS MP, MINISTER FOR

IMMIGRATION AND CITIZENSHIP

\section{PART II THE DYNAMICS OF SOCIAL COHESION}

5 The landmark of Cronulla 61

JOCK COLLINS

6 Policing the other: Lebanese young people in a climate of conflict 70 ROB WHITE

7 Religious resurgence and diversity and social cohesion in Australia 80 GARY D. BOUMA AND ROD LING

8 Family and nation: the Indigenous/non-Indigenous relationship 90 TIM ROWS 
9 Social cohesion and cultural fragility: a paradox of Indigenous rapports with Eurasian Australia 103

ROBERT NELSON

10 Educational attainments, inter-ethnic marriage and social cohesion 114 SIEW-EAN KHOO

\section{PART III INFLUENCES AND RESPONSES IN SEARCHING FOR}

\section{SOCIAL COHESION}

11 Unions, the workplace and social cohesion 131 SANTINA BERTONE

12 Education and social cohesion 142 HURRIYET BABACAN

13 The media and social cohesion 158 ANDREW JAKUBOWICZ

14 The problem of sport and social cohesion 170 BRETT HUTCHINS

15 Counter-terrorism and the politics of social cohesion 182 JENNY HOCKING

16 Social cohesion and human rights: would a bill of rights enhance social cohesion in Australia? 191

GABRIELLE MCKINNON

References 204

Index 221

\section{Foreword}

Australia is one of the world's most diverse societies. It is a country of immigration, nearly half of whose population was born, or is the child of a parent born, overseas. Down the decades, successive Australian governments have pursued planned immigration intake programs, accompanied by settlement services. In addition, ever increasing temporary migration and tourism have been facilitated and encouraged, enlarging further the diverse composition of Australian society.

It is a substantial achievement that this persisting population expansion from a multitude of varying cultures has been achieved with very little divisiveness, though the lack of Indigenous equality remains a thorn.

With the unparalleled persistence of steady, strong economic growth in the past 11 years, skill shortages and bottlenecks have emerged despite the immigration program and temporary entry of workers. And it is highly likely that substantial increases in immigration intake targets will ensue, even though current levels are at their highest for 20 years.

It is clear that, in order to achieve and accommodate this larger inflow, social cohesion will be especially important at a time when there are potential tensions arising indirectly from the international 'war on terror' and the freer movement of people in a globalised world.

Social Cohesion in Australia is, therefore, a well-timed publication. Its 16 chapters by distinguished scholars from a variety of universities and from the Commonwealth Government, cover an excellent range of topics, from the quest for harmony, to social cohesion and sport, the arts, education, the workforce, Indigenous communities, the media, inter-ethnic marriage, the landmark of Cronulla, the Commonwealth's view, human rights, and definition and measurement.

Social Cohesion in Australia is part of the Scanlon Foundation's major Social Cohesion Research Project and has been undertaken through Scanlon funding provided to a partnership between the Monash Institute for the Study of Global Movements and the Australian Multicultural Foundation.

We congratulate the editors and authors of this important volume. Their work makes a major contribution to understanding and knowledge about the constituent parts of social cohesion in a country whose experience is of interest not only to its inhabitants but also internationally.

Professor Richard Larkins AO Vice Chancellor and President

Monash University

Sir James Gobbo AC CVO

Chair

Australian Multicultural Foundattion

Mr Peter Scanlon

Chair

Scanlon Foundation 


\section{Contributors}

Hurriyet Babacan is Professor of Social and Cultural Development in the Institute for Community Engagement and Policy Alternatives at Victoria University.

Santina Bertone is Associate Professor and Head of the Work and Economic Policy Research Unit, and Associate Dean (Research) in the Faculty of Business and Law at Victoria University.

Gary D. Bouma is Professor of Sociology and UNESCO Chair in Intercultural and Interreligious Relations - Asia Pacific at Monash University.

Jock Collins is Professor in the School of Finance and Economics at the University of Technology in Sydney.

Emma Dawson is Research Fellow at the Institute for the Study of Global Movements, and a PhD scholar at the National Centre for Australian Studies, Monash University.

Nick Economou is Senior Lecturer and Head of Politics in the School of Political and Social Inquiry at Monash University.

Jenny Hocking is Professor and Deputy Head of the National Centre for Australian Studies and Director of Research for the School of Humanities, Communications and Social Sciences at Monash University.

Brett Hutchins is Lecturer in Communications and Media Studies at Monash University.

Andrew Jakubowicz is Professor of Sociology at the University of Technology in Sydney.

James Jupp AM is the Director of the Centre for Immigration and Multicultural Studies in the Research School of Social Sciences at the Australian National University.

Siew-ean Khoo is Senior Fellow in the Demography and Sociology Program at the Australian National University.

Liudmila Kirtpitchenko is a researcher at the Scanlon Foundation for Social Cosion Research Program and a PhD candidate in Sociology in the School of Political and Social Inquiry at Monash University.
Rod Ling is Post Doctoral Fellow in the School of Sociology at Monash University.

Andrew Markus is Professor of Jewish Civilisation and the Director of the Australian Centre for the Study of Jewish Civilisation at Monash University Gabrielle McKinnon is Research Associate in the Centre for International Governance and Justice at the Australian National University.

Robert Nelson is Associate Professor and Associate Dean, Research and Graduate Studies, and Acting Head of Department in the School of Visual Arts at Monash University.

John Nieuwenhuysen AM is Professor and Foundation Director or the Monash Institute for the Study of Global Movements; Chair of the Board, VITS Language Link; a member of RMTT University Council, and a member of the board of the Australian Multicultural Foundation.

Tim Rowse is Senior Research Fellow in the History Program of the Research School of Social Sciences at the Australian National University.

Rob White is Professor of Sociology at the University of Tasmania. 


\section{Tables}

2.1 Bernard's typology of social cohesion

2.2 The domains of social cohesion

3.1 Modelling social cohesion

7.1 The size and proportion of selected Australian religious groups in the 1947, 1971, 1996 and 2001 Censuses

7.2 Changes in Australia's religious profile, 1996-2001

10.1 Percentage with post-school qualifications: men and women aged $25-44$ in Australia 2001 by birthplace.

10.2 Participation in education, youth aged $15-24$ by birthplace, Australia 2001

10.3 Percentage of first and second generation youth aged 15 -24 enrolled in education, by ancestry, Australia 2001

10.4 New migrants' social/community participation by level of education

10.5 Percentage of partnered men and women with spouse of a different ancestry by ancestry and generation, Australia 2001

12.1 Religious affiliation of independent schools

13.1 Modes and examples of media practices

\section{Acknowledgments}

In 2006, the Scanlon Foundation sponsored a major research initiative on Social Cohesion in Australia, which was launched by the Governor of Victoria, Professor David de Kretser AC, in June of that year.

The Australian Multicultural Foundation and the Monash Institute for the Study of Global Movements were funded by the Scanlon Foundation to undertake the project in six component parts: Mapping settler patterns in Australia; Identifying the components of social cohesion; Designing an attitudinal survey; Undertaking a benchmark survey; Reviewing how social cohesion in Australia might be best attained; and Canvassing the comparative international experience by case studies of minorities in Australian and international situations. This volume is concerned with the fifth component of the project and asks: how can social cohesion in Australia be constructively attained?

The editors wish to thank the Scanlon Foundation and its chair, $\mathrm{Mr}$ Peter Scanlon, for their generous funding of this work. We are also grateful to the Chair of the Board of the Australian Multicultural Foundation, Sir James Gobbo $\mathrm{AC}, \mathrm{CVO}$, and its Executive Director, Mr Hass Dellal OAM, for material assistance in conceiving the idea and consistent help in its execution.

The editors wish in particular to thank the eminent authors who have produced an excellent, diverse collection of chapters for the book. They did so with cheerfulness, great professionalism and impressive punctuality.

We owe also a special debt of gratitude to the Administrator of the Monash Institute for the Study of Global Movements, Sahar Sana. Sahar has provided outstandingly efficient and extremely helpful assistance.

James Jupp John Nieuwenhuysen Emma Dawson 
Introduction

John Nieuwenhuysen

There are many features of a society that can undermine its cohesiveness. These include the distribution of income, wealth, employment and opportunity, as well as access to services, voting rights or citizenship among various segments of the population. This book is, however, concerned with one principal question: how can Australia, with its considerable cultural diversity and continuing high (permanent and temporary) immigrant intake, remain socially cohesive? The volume is by no means encyclopaedic. But it covers, with contributions by 16 authors, an important series of aspects of several of the perceived indicators of social cohesiveness in Australia.

Part $I$ surveys the historical quest for harmony in Australia, and the conditions and possible means of measuring social cohesion, as well as current federal government initiatives to attain it. The chapters in Part II consider the landmark of Cronulla; ethnically based youth groups; religious resurgence and diversity; Indigenous Australia, and aspects of cultural fragility; and educational attainment and inter-ethnic marriage. Part III covers unions and the workplace; education; the media; sport; terrorism and politics; and human rights.

The book concentrates on immigration, which has been a central part of Australia's history since first European settlement in 1788. It has been at the hear of the creation of a dynamic society and has helped economic growth. Much of immigration's success has depended on the absence of marked social conflict and division through the arrival from overseas, in peaks and troughs, of so many millions of people from extremely diverse backgrounds.

Current (2007) immigration intakes under the planned program are at their highest levels in 20 years. They are expected to rise substantially in the near future, and are exceeded by even greater numbers of temporary arrivals. A in previous years, immigration policy remains controversial. But public opinion polling has seldom indicated that it is a major issue, ranking it as of very secondary importance in the public mind relative to the economy, employment, health and education.

But there are two special features in the current debate which mark a turning point from the past. The first is an ever more rapidly globalising world which includes a much freer movement of people. The second is the violent attacks on civilians in different countries, in response to which a 'war on terror' has been joined by the Australian government. Security and other legislation have ensued, casting suspicion on the Muslim community (which numbers 300000 of which one-third are locally born). Riots in the Sydney suburb of Cronulla in December 2005 unleashed scenes which shocked Australia. This led to much 
activity by governments and Muslim and other community leaders, engendering public discussion and plans to alter federal government multicultural policies. It is in this context that the book is set.

There are variations in the conception of social cohesion among the different authors from the perspective of several disciplines. Consequently, the editors have left it to them, within a broad frame, to apply these conceptions of social cohesion, and how it can be maintained or undermined, to their analyses. Nonetheless, there are many shared aspects of the definitions used. These derive mainly from the idea that social cohesion reflects the strength of shared values, a sense of common identity and of belonging to the same community. Khoo (chapter 10) points out that recent work in Western societies suggests five dimensions of social cohesion: belonging (shared values, identity, commitment); inclusion (equal opportunities for access); participation (engagement in structures and systems); recognition (respect and tolerance); and legitimacy (pluralism). Each of these, as well as those mentioned by Jupp, appears in the various chapters of the book.

Overall, the editors have adopted Jenson's (1998a,b) conclusion that 'there is no single way of even defining [social cohesion]. Meanings depend on the problem being addressed and who is speaking'.

In chapter 1, James Jupp notes that Australia is among the most cohesive and harmonious societies on earth, one based on 'stable institutions, high living standards, economic expansion and isolation from zones of conflict'. Why then, he asks, is there so much anxiety about social cohesion? While much of the debate about serious divisions resulting from multiculturalism is 'quite hysterical', there remain problems in the area of social justice and equality. He gives a substantial by which social cohesion is maintained, including a sound economy with equitable distribution of goods and services; a basic stock of values and traditions; and a high level of trust between citizens and authorities.

In chapter 2, Andrew Markus and Liudmila Kirpitchenko provide Canadian, British and other definitions of social cohesion. The Canadian quotations emphasise that ing in individuals a sense of belonging and recognition. The British examples view a cohesive community as possessing a common vision, with the diversity of the backgrounds of its members being positively valued and the provision of equal opportunities for all in society.

In chapter 3, Nick Economou notes that observers have some facility in providing varying definitions of social cohesion and saying how it might be assessed. But they are 'much better at identifying those moments where social cohesion breaks down'. After reviewing different approaches to social cohesion and its definitions in Europe, North America and elsewhere, he draws attention to 'the potential for the notion of "social cohesion" to be contentious and value-laden, potential for the notion of "social cohesion" to be contentious and value-laden, particularly where analysts seek to quantify the extent to which there are shared
values within a community'. He illustrates this by citing ambivalent attitudes to linguistic diversity: viewed positively by multiculturalists but negatively by assimilationists. He provides a brief review of the different ways of measuring social cohesion. The difficulty of defining social cohesion is reflected in the complexities of the means of measurement that he outlines. The concept of social cohesion is value-laden and so is the task of finding adequate measuring rods.
Nonetheless, it is an important task and is part of the Scanlon Social Cohesion Research initiative, of which this book is one project.

Concluding Part I, chapter 4 is an outline of the Commonwealth's policies and approaches to creating a socially cohesive and economically thriving country under a planned long-term immigration program. Presented by the Department of Immigration and Citizenship, this paper gives a very positive view of migration to Australia and its consequence for society and the economy. It celebrates Australia's success in integrating people from many nations and cultures around the world - 'respecting people's differences and providing opportunities for one to belong and participate as full members' - and lists several factors that contribute to this social cohesion.

Part II commences in chapter 5 with Jock Collins' analysis of inter- and intra-ethnic conlict, a commonly used indicator of the degree of divisiveness in communities. He uses overseas experience as a lens through which the riots at Sydney's Cronulla beach in December 2005 can be viewed, and set in proper perspective. While not denying the ugliness of the riots, he highlights their more extreme, sustained and violent counterparts in other eras and countries. He also details desirable policy responses to the riots, including jobs, education, urban renewal, public housing and space, more sensitive and less sensational media coverage, and community relations. He concludes that the Cronulla riots were 'an expression of ethnic tensions in one of the world's most cosmopolitan cities'.

In chapter 6 , Rob White deals with one of the most important aspects of social cohesion and its maintenance in Australia: the transformation of social difference into social deviance, where people who have grown up here are vilified as outsiders. The response of many of thesepeople is to affirm their social presence by joining a gang. Three intervention issues are identified: perceptions that youth gangs are a danger to the community generate action from police, irrespective of what is happening at the grassroots level; political and economic conditions for potential growth in gang-related activity do exist, and need to be forestalled. most discussions of gangs have been racialised, with ethnic minority youth the main subject of attention.

In chapter 7, Gary Bouma and Rod Ling note that the global movement of ideas, people and capital has accompanied religious renewal, and altered the flow influences in religion from north to south to the opposite direction. Numbers of religious groups have been increasing as well as their diversity, and include growing variety of uncontrolled and less organised forms of religious life. The previous policies for managing this diversity are under challenge, demanding new sensitivities to gauge whether religion helps create or diminish social cohesion. For this challenge, it is critical to distinguish between revitalising and radicalising influences in religious activity.

In chapter 8, Tim Rowse suggests that the way in which people in Australia view cohesion between the Indigenous and non-Indigenous populations will be affected by how they think about cohesion within Indigenous Australia. Indigenous Australians have the double challenge of how to live within a country where they are disadvantaged, and how to live with each other. Of special importance are the views of Noel Pearson that Indigenous people have been 'poisoned' by their access to welfare benefits. 
Closely related to Rowse's work is Robert Nelson's chapter 9, where he discusses the relationship between arts and social cohesion by alluding to the uniformist impact of globalisation, where people of diverse background are brough formist impact of guls in's together. He notes Australia's success a but adds that this ' $m$ ir aculous peaceful nulticultural existence' has been bought at the expense of Indigenous Australians. He makes an impassioned attack on globalisation, which 'entails a new persistence of persuasive commercial language, in which ownership of the ideal way to be, look, think, and aspire, inheres in forin which ownes local and natural modes of deportment are eign places; and meanwhile the old local and ntassing' expropriated, deemed unfashionable, redundant, backward and embarrassing

In chapter 10, two other important and well-established indicators of Australian social cohesion - educational attainment and inter-ethnic marriage - are tralian social coheson - Khoo. Education is seen as contributing to social inclusivereviewed by Sich ness through provision of greater human capital, enabling increased economic participation and integration. Inter-ethnic marriage is also regarded as one of the most definitive indicators of immigrant integration into the local community, since 'it is seen as the outcome of close social interaction between people of nity, since it is seen as the Khoo reaches encouraging conclusions for the future of different communities. Whoo reach counts: statistical evidence shows that levels social cohesion in Australia on both couns of educational attainment are higher in young than adult migrant generations, and implies greater engagement with the general community; and there is also clear evidence that migrants in the second generation are more likely than their parents were to marry outside their own ethnic group. And the third generaparents were to marry outsidren of Australian-born parents, is even less likely to maintain the ethnic culture of their grandparents.

Part III deals with the influences and responses in searching for social cohesion in Australia. In chapter 11, on employment and the unions, Santina Bertone in Austrila in mortant for new arrivals to a country emphasises that encolished residents, otherwise they become marginalised. Her than to longer established residents, otherwise they bectin analysis reveals some growing pressure points in the Australian labour market which threaten social cohesion: the disproportionate representation of workers of non-English-speaking background in the lower jobs, and the baneful impact of non-English-speaking bacther anti-refugee and anti-Muslim rhetoric, point towards future social unrest and anti-refugee friction.

In chapter 12, Hurriyet Babacan cites Durkheim's observation that society depends for its existence on 'a sufficient degree of homogeneity. Education perpends petuates and ning, the essential simlarities that collective life deman that both the definition and measurement of social cohesion in the context of education's contribution to it are problematic. This is partly because education's impact on social cohesion 'may well be greatly outweighed by more powerful impact on social cohesion factors at the national level'. She notes the major chalinstitutional and cultural facto social cohesion. These are lenges confronting education in its relationship with social cohesion. These are both micro issues such as cultures, languages and experiences of students

their families, and macro issues such as racial stratification and inequality.

Andrew Jakubowicz's chapter 13 notes the position of the media in providing primary machinery in the promotion of both social cohesion and social conflict'. In reviewing the evidence, and using Cronulla as a part case study, he concludes that there is a need to view the media's overall effect on social cohesion with that there is a need to view
considerable discernment.

In chapter 14, Brett Hutchins notes a lack of critical perspective infusing much popular writing about sport, which is 'a social activity that divides as much as it unites'. In recollecting and celebrating past sporting feats, it is often forgotten that many sports have blemished records of appealing to those of non-Englishspeaking backgrounds, Indigenous competitors, and women. There is a need 'to reframe the problem of sport and social cohesion'. It is unrealistic to suppose that sport can somehow 'fix social problems or transcend cultural divides'.

Jenny Hocking in chapter 15 trenchantly outlines new security legislation and its impact on inter-ethnic relations. Since September 11, 2001, the federal government has passed more than 30 pieces of legislation to combat acts of terrorism, and the agencies of state concerned with security have received dramatic increases in powers and resources, creating an 'effective second tier of quasijudicial process outside the established criminal justice system and free of key legal protections'. She points to several aspects of the new security regime, among them Executive proscription powers, which have, in their selective application, disturbing implications for inter-ethnic relations. In concluding, she notes the irony of Australia's imitation of overseas anti-terrorist legislation, quoting Malcolm Fraser: 'The country that has most successfully handled multicultural issues over the last 50 years is to go down a track, practised by countries that have handled these same issues less well and with less harmony.'

Finally, in chapter 16, Gabrielle McKinnon asks, would a bill of rights enhance social cohesion in Australia? Australia is the only Western democratic nation which remains reluctant to make human rights enforceable through a domestic bill of rights. Opponents argue that any legislative protection of human rights of individuals over the community as a whole would erode the cohesiveness of Australian society. She reviews the possibility that an Australian bill of rights could assist social cohesion by providing a set of common values relevant to a multicultural society and a mechanism for mediating conflict between competing interests within the community.

The essays in this book describe a mixture of the overall success of the immigration program over recent decades, under multicultural policies, and some problempric questions for the future. Australia's cosmopolitanism has grown apace but without some of the problems (for example ghettoisation) experienced in other immigrant-receiving societies. The inflow of people to Australia has been supported by settlement services, in particular English language training facilities, which have assisted employment opportunities and economic mobility for new arrivals. And on some key indicators of social cohesion, for example greater community engagement of young second-generation migrant groups, the omens are good.

Nonetheless, several question marks are raised by the various authors: issues of marginalisation of the overseas-born in the workforce; the consequences of

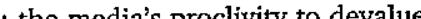
minorities who appear not to conform to core cultures; the social estrangement 
and exclusion of Indigenous people from the prosperity and degree of economic participation of the broader population; the difficulties which some mainstream religious organisations and the population generally have in coming to terms with new, less familiar groupings, and the reduced capacity of older religious structure to deliver social cohesion; and the feelings of marginalisation and alienation among young people in the face of hostility and vilification, which leads them to affirm their social presence and validate their lives by joining a gang.

As in other countries, such as Britain, one of the major new challenges to social cohesion policies in Australia is a greater and deeper diversity among new residents. Sometimes that greater diversity, as part of a globalised world, means that imported tensions are being reflected in Australian public places. Among these are the consequences for inter-ethnic relations of security legislation designed to prevent in Australia the violent terrorist attacks which have occurred in overseas countries, such as the United States, Britain, Spain and Indonesia. For some communities in Australia, life has started to feel different since the attacks in New York in 2001 and their successors in London, Madrid and Bati.

At the same time, some resident Australians question alleged 'special treatment' for immigrants, and develop resentment and grievance.

In this, there is a remarkable similarity between the Australian scene and that elsewhere, for example Britain. The British Parliamentary Secretary for Communities, Ruth Kelly, could have been speaking of Australia when she said:

The issue became a catalyst for a debate about who we are and what we are as a country. About what it means to live in a town where the faces you see on the way to the super Abut the supermarket havech we have moved from a period of uniform consensus on the value of multiculturalism, to one where we can encourage that debate by questioning whether it is encouraging separateness. (Speech at launch of Commission on Integration and Cohesion, London, 28 August 2006.)

Echoing this in political theory are several voices, including Francis Fukuyama, who considers that the 'old multicultural model' of countries such as the Netherlands and Britain needs to be replaced since, out of a 'misplaced sense of respect for cultural difference', it 'ceded too much authority to cultural communities to define rules'. But, he adds, liberal societies have their own values and 'cultures that do not accept these premises do not deserve equal protection'.

In international and Australian debate basic questions are being asked. The Australian government for its part has formally distanced itself from the long established era of multiculturalism. After showing distaste for the word 'multiculturalism' over its first ten years of office, the Howard government has changed the name of the former Department of Immigration and Multicultural Affair (DIMA) to the Department of Immigration and Citizenship (DIAC). State governments in Australia are unlikely at present to follow this example. But the Australian government's move makes the messages of this book especially topical and important. They stress the success of Australia's past. But caution and care are necessary lest the bases of that success are neglected by all the various governments, agencies and communities concerned in coming to terms with the fresh challenges of today and tomorrow.

\section{DEFINING, MEASURING AND SEEKING SOCIAL COHESION \\ PART I}

SOCIAL COHESION

